\title{
Competitive Effects of Weeds and Beneficial Effects of Mulching on Coconut Seedlings
}

\author{
S. U. REMISON and G. MGBEZE \\ Physiology Division, Nigerian Institute For Oil Palm Research, P. M. B. 1030, \\ Benin, Nigeria
}

\section{ABSTRACT}

Dwarf coconut seedlings were raised in polybags under four mulching treatments (no mulch, coconut husk, oil palm bunch refuse and grass) and two weeding regimes (designated Wo and W1) in the nursery. Weeding was done once every month in W1 plots whilst Wo plots were left unweeded.

Weed competition reduced the growth of coconut seedlings a great deal and the unweeded and unmulched plants were not vigorous enough for transplanting. Weeds reduced dry matter yield of leaves, stem and roots in unmulched plots by 61,46 and $44 \%$ respectively. Mulching was beneficial and reduced competitive effects of weeds. Mulching increased plant height, girth and dry matter yield. At harvest, leaves formed the greatest proportion of the dry matter; the mean being $171.6 \mathrm{~g}$ compared with 20.8 and $43.2 \mathrm{~g}$ for stem and roots respectively. Soil temperatures were only moderately reduced by mulching. Coconut husk suppressed weeds the most but oil palm bunch refuse increased $\mathrm{K}$ content of soil more than any other mulch material.

\section{INTRODUCTION}

Coconut research has been intensified in recent years in Nigeria because of its increasing demand not only for its oil but as an aesthetic crop. Initially nurseries were conventional on ground beds but these have been replaced in recent times by raising nuts in polybags in which plants have been found to be more vigorous, easier to handle and ball of earth containing the roots is intact at field planting (Chang, 1978; Wuidart, 1981).

The nuts are grown in polybags for 9-12 months in nurseries before transplanting to the field. During this period there must be adequate maintenance if the plants are to be vigorous and transplantable. Among other cultural practices the polybag must be kept weedfree. Weed competition has been reported to reduce yield in field and plantation crops in Nigeria (Okigbo, 1978; Oladokun, 1978; Komolafe, 1978; Remison, 1979). The extent of such reduction is not well known in the nursery. Weeds harm crops by competing directly for light, water and nutrients as well as sometimes by specific inhibitory effects on the crops' root system (allelopathy). Monthly weeding rounds are recommended for both polybags and intervening ground in oil palm nurseries (Bevan and Gray, 1969). This means about nine or more times for the duration of the plants in the nursery. This is labour intensive and mulching could be one way of reducing the competitive effects of weeds.

The aim of this experiment was therefore to find out the extent to which mulching can reduce competitive effects of weeds in nursery grown coconut seedlings. 


\section{S. V. REMISON and G. MGBEZE}

\section{MATERIALS AND METHOD}

The experiment was carried out at the Nigerian Institute for Oil Palm Research (NIFOR), Near Benin in a rainforest zone with a bimodal rainfall. Dwarf green coconut variety was used. Seednuts were planted in polybags $(35 \times 40 \mathrm{~cm}$ laid flat, 500 gauge $)$ with a single $2.5 \mathrm{~cm}$ inverted V-cut drainage hole in November 1982 and seedlings were selected for uniformity at 2-leaf stage in February 1983. The polybags were spaced $45 \times 45 \mathrm{~cm}$ apart and the experimental area was peripherally guarded with coconut seedlings.

Four mulching treatments (no mulch, coconut husk, Oil Palm bunch refuse and grass) and two weeding regimes (no weeding, W0 and weeding, W1) were used in a $4 \times 2$ factorial scheme. The experiment was replicated five times and each treatment was represented by a sample size of five seedlings, giving a total of twenty seedlings per treatment. Weeding was done once every month. Soil used had a $\mathrm{pH}$ of $5.8,0.28 \% \mathrm{~N}$, $39.1 \mathrm{ppm}$ P, 0.14 meq K, 2.35 meq $\mathrm{Ca}$ and $0.85 \mathrm{meq} \mathrm{Mg.} \mathrm{Meteorological} \mathrm{conditions}$ during the period of experimentation are shown (Table 1).

Table 1. Meteorological conditions at nifor main station benin in $\mathbf{1 9 8 3}$

\begin{tabular}{|c|c|c|c|c|c|c|c|}
\hline & & Min. & $\begin{array}{l}\text { (oC) } \\
\text { Max. }\end{array}$ & $\underset{(m m)}{R a i n f a l l}$ & $\begin{array}{r}\text { Relative } \\
\text { humidity } \%\end{array}$ & $\begin{array}{l}\text { Mean Daily } \\
\text { sunshine (hr) }\end{array}$ & $\begin{array}{l}\text { Total sun and } \\
\text { sky radiation }\end{array}$ \\
\hline $\begin{array}{l}\text { January } \\
\text { February } \\
\text { March } \\
\text { April } \\
\text { May } \\
\text { June } \\
\text { July } \\
\text { August } \\
\text { September } \\
\text { October } \\
\text { November } \\
\text { December }\end{array}$ & $\begin{array}{l}\cdots \\
\cdots \\
\cdots \\
\cdots \\
\cdots \\
\cdots \\
\cdots \\
\cdots \\
\cdots \\
\cdots \\
\cdots \\
\cdots\end{array}$ & $\begin{array}{l}13.9 \\
18.8 \\
24.2 \\
23.7 \\
23.0 \\
22.3 \\
22.2 \\
21.6 \\
22.3 \\
22.4 \\
22.9 \\
21.6\end{array}$ & $\begin{array}{l}32.9 \\
30.1 \\
35.8 \\
35.2 \\
33.1 \\
29.7 \\
29.1 \\
27.4 \\
29.4 \\
31.5 \\
32.8 \\
31.7\end{array}$ & $\begin{array}{r}0.0 \\
18.9 \\
3.2 \\
123.8 \\
297.2 \\
238.4 \\
172.4 \\
106.5 \\
338.0 \\
81.7 \\
75.9 \\
42.7\end{array}$ & $\begin{array}{l}54.7 \\
67.4 \\
76.8 \\
77.8 \\
79.9 \\
87.6 \\
86.8 \\
89.3 \\
87.1 \\
82.9 \\
83.3 \\
86.4\end{array}$ & $\begin{array}{l}3.4 \\
4.5 \\
3.9 \\
6.6 \\
6.6 \\
3.4 \\
3.5 \\
1.5 \\
3.9 \\
5.3 \\
6.9 \\
6.8\end{array}$ & $\begin{array}{l}368.2 \\
419.9 \\
402.7 \\
416.3 \\
324.5 \\
284.6 \\
304.7 \\
241.3 \\
330.5 \\
375.4 \\
413.7 \\
354.1\end{array}$ \\
\hline
\end{tabular}

Plant height, number of leaves, stem girth and soil temperatures were monitored monthly. Soil temperature was recorded at $1 \mathrm{pm}$ at $10 \mathrm{~cm}$ depth. Chemical composition of the soil was determined at three months of commencement of mulching treatment and at harvest in November 1983. At harvest the plants were separated into leaves, stem and roots, thoroughly washed and oven dried.

\section{RESULTS}

Soil temperatures were only moderately reduced by mulching treatment (Table 2) and were quite significantly greater than atmospheric temperatures.

From February to April 1983, the height of plants mulched with bunch refuse and grass were significantly different from the control and plants mulched with coconut husk (Table 3). Significant interaction of weeding $\times$ mulching was apparent from May when it became abundantly clear that under the no weeding' regime mulching was beneficial and significantly increased plant height. Conversely, when plants were kept weed free, mulching had no effect on height. Mulching or weeding had no effect on number of leaves or leaf splitting. 
Effects of weeds and mulching on Coconut Seedlings

Table. 2. Soil temperatures $\left({ }^{\circ} \mathrm{C}\right)$ in polybags at $10 \mathrm{~cm}$ depth

\begin{tabular}{|c|c|c|c|c|c|c|c|c|}
\hline & & April & May & July & August & September & October & November \\
\hline \multicolumn{9}{|l|}{ No Weeding (Wo) } \\
\hline Control (no mulch) & $\ldots$ & 41.6 & 38.3 & 28.9 & 30.4 & 34.4 & 37.3 & 38.9 \\
\hline Coconut husk & $\ldots$ & 40.1 & 38.5 & 28.7 & 29.8 & 33.7 & 36.3 & 36.9 \\
\hline Bunch refuse & $\ldots$ & 40.2 & 38.8 & 28.7 & 30.7 & 34.4 & 37.7 & 37.7 \\
\hline Grass & $\ldots$ & 40.2 & 38.2 & 28.9 & 30.7 & 33.6 & 37.7 & 38.4 \\
\hline \multicolumn{9}{|l|}{ Weeding $\left(W_{I}\right)$} \\
\hline Control (no mulch) & $\ldots$ & 41.6 & 39.1 & 30.2 & 30.0 & 34.0 & 38.7 & 38.3 \\
\hline Coconut husk & $\ldots$ & 40.5 & 38.7 & 28.5 & 31.2 & 34.2 & 36.1 & 38.1 \\
\hline Bunch refuse & $\ldots$ & 40.4 & 38.4 & 29.4 & 31.0 & 35.2 & 37.2 & 38.1 \\
\hline Grass & $\ldots$ & 40.4 & 38.8 & 29.7 & 30.9 & 34.4 & 38.3 & 38.8 \\
\hline
\end{tabular}

Table 3. Effects of weed competion and mulching on plant height (cm) of coconut seedlings

\begin{tabular}{|c|c|c|c|c|c|c|c|c|c|c|}
\hline \multicolumn{11}{|c|}{ Time (months) } \\
\hline & & $F$ & $M$ & $A$ & $M$ & $J$ & $J$ & $A$ & $s$ & 0 \\
\hline \multicolumn{11}{|l|}{ No Weeding (Wo) } \\
\hline $\begin{array}{l}\text { Control (no mulch) } \\
\text { Coconut husk } \\
\text { Bunch refuse } \\
\text { Grass } \\
\text { Mean }\end{array}$ & $\begin{array}{l}\cdots \\
\cdots \\
\cdots \\
\cdots \\
\cdots\end{array}$ & $\begin{array}{l}53.8 \\
59.4 \\
69.5 \\
66.0 \\
62.2\end{array}$ & $\begin{array}{l}65.2 \\
73.7 \\
86.0 \\
81.9 \\
76.7\end{array}$ & $\begin{array}{l}68.5 \\
83.3 \\
95.5 \\
94.3 \\
85.4\end{array}$ & $\begin{array}{r}70.1 \\
91.6 \\
99.5 \\
100.9 \\
90.5\end{array}$ & $\begin{array}{r}69.4 \\
92.7 \\
100.3 \\
105.5 \\
92.0\end{array}$ & $\begin{array}{r}72.6 \\
95.4 \\
106.7 \\
107.2 \\
95.5\end{array}$ & $\begin{array}{r}72.3 \\
99.3 \\
108.6 \\
109.6 \\
97.5\end{array}$ & $\begin{array}{r}74.1 \\
103.7 \\
110.4 \\
112.0 \\
100.1\end{array}$ & $\begin{array}{r}78.6 \\
108.7 \\
114.2 \\
117.6 \\
104.8\end{array}$ \\
\hline \multicolumn{11}{|l|}{ Weeding $\left(W_{1}\right)$} \\
\hline $\begin{array}{l}\text { Control (no mulch) } \\
\text { Coconut husk } \\
\text { Bunch refuse } \\
\text { Grass } \\
\text { Mean } \\
\text { SE+ }\end{array}$ & $\begin{array}{l}\cdots \\
\cdots \\
\cdots \\
\cdots \\
\cdots \\
\cdots\end{array}$ & $\begin{array}{l}61.7 \\
58.4 \\
65.4 \\
66.5 \\
63.0 \\
5.66\end{array}$ & $\begin{array}{l}76.1 \\
71.4 \\
81.8 \\
80.1 \\
77.4 \\
5.67\end{array}$ & $\begin{array}{l}85.3 \\
81.3 \\
92.6 \\
88.4 \\
86.9 \\
6.12\end{array}$ & $\begin{array}{l}90.3 \\
86.8 \\
97.3 \\
92.3 \\
91.7 \\
5.81\end{array}$ & $\begin{array}{r}93.5 \\
91.1 \\
100.5 \\
95.4 \\
95.1 \\
6.08\end{array}$ & $\begin{array}{l}95.1 \\
96.0 \\
94.6 \\
92.4 \\
94.5 \\
8.35\end{array}$ & $\begin{array}{r}101.9 \\
98.3 \\
100.9 \\
105.6 \\
101.7 \\
7.54\end{array}$ & $\begin{array}{r}109.8 \\
102.2 \\
110.3 \\
109.6 \\
108.0 \\
7.45\end{array}$ & $\begin{array}{l}108.9 \\
108.3 \\
115.2 \\
112.7 \\
111.3 \\
8.1\end{array}$ \\
\hline
\end{tabular}

There was generally no significant difference in stem girth with the three mulch materials used. But they differed from the no mulch plots markedly from April to the end of the experiment (Fig. 1). There was significant weed $x$ mulch interaction in September $(P<0.05)$ and October $(P<0.01)$ when under 'no weeding' regime plants mulched with coconut husk had the greatest girth while under weeding regime plants with bunch refuse had the greatest girth. Weed competition had no effect on stem girth from commencement of the study up to May but from June, it reduced girth significantly (Fig. 2).

At harvest, leaves formed the greatest proportion of the dry matter (Table 4); the mean being $171.6 \mathrm{~g}$ compared with 20.8 and $43.2 \mathrm{~g}$ for stem and roots respectively. There was a significant response $(P<0.05)$ to mulching treatment in the partition of dry matter to plant parts. Though there was no difference between the mulch materials per se, the control (no mulching) differed markedly. The mean weight with mulching materials was $58.5,41.7$ and $48.3 \%$ greater than the control for leaves, stem and roots respectively. Total dry matter yield (excluding the nut) increased significantly $(P<0.05)$ with mulching (Fig. 3) . This was clearly more apparent under 'no weeding' regime. 
S. V. REMISON and G. MGBEZE

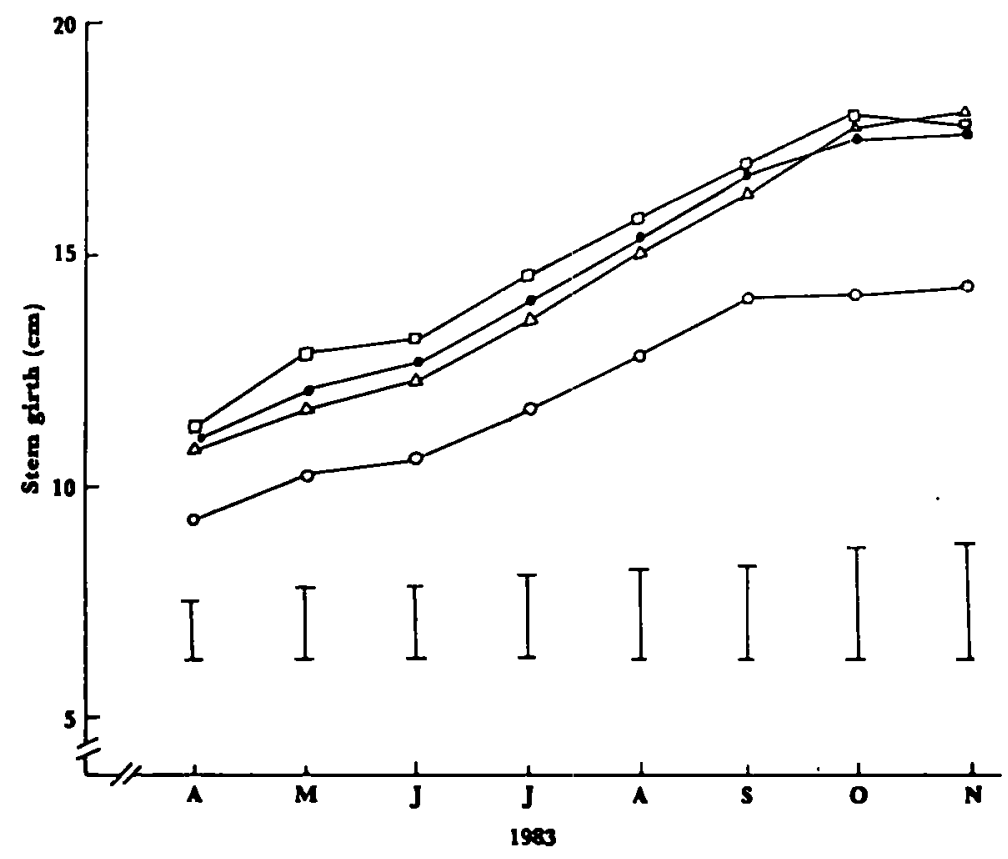

Fig. 1 Effect of mulching on stem girth ( $\mathrm{cm}$ ) of coconut seedlings $O$, control (no mulch); $\Delta$, coconut husk: $\square$, bunch refuse; O grass. Vertical bars represent L. S. D. $(P=0.05)$.

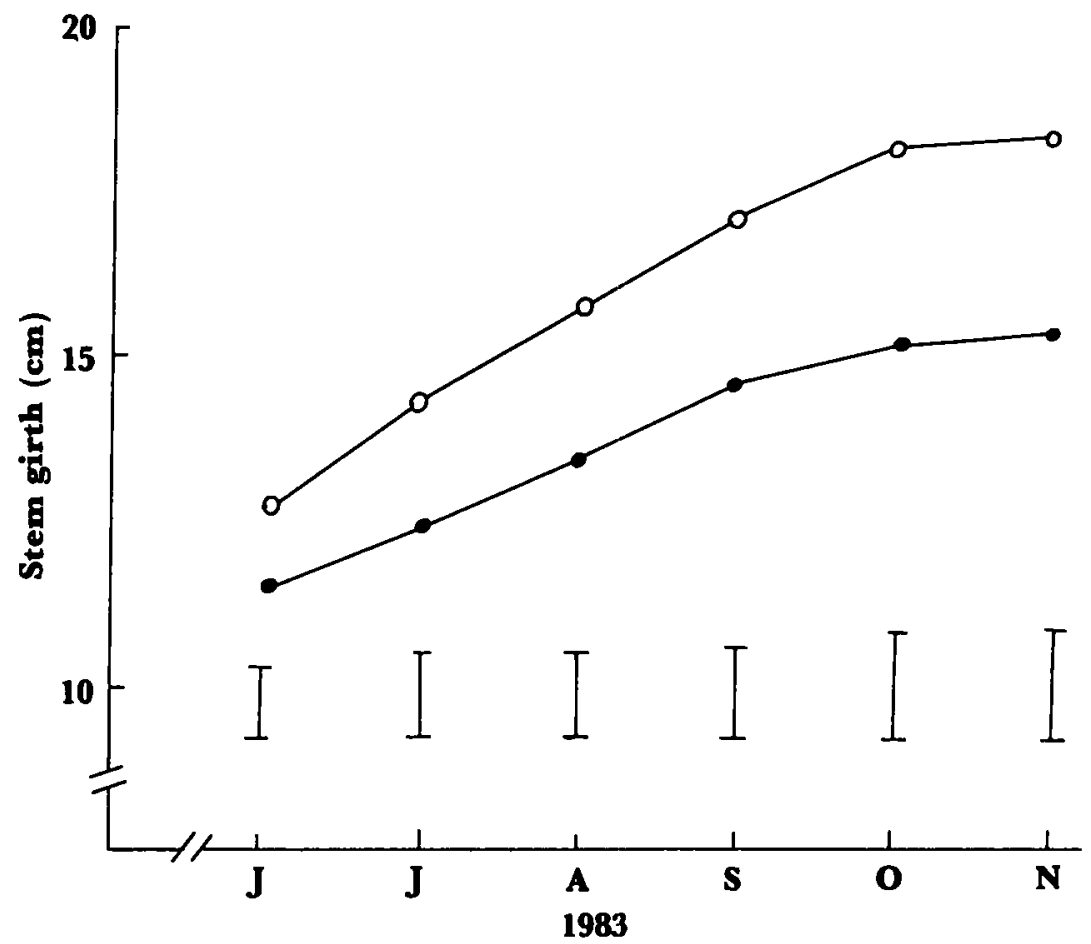

Fig. 2 Stem girth (cm) of coconut seedlings as influenced by weeding $(O)$ and no weeding (O). Vertical bars represent L. S. D. $(P=0.05)$. 


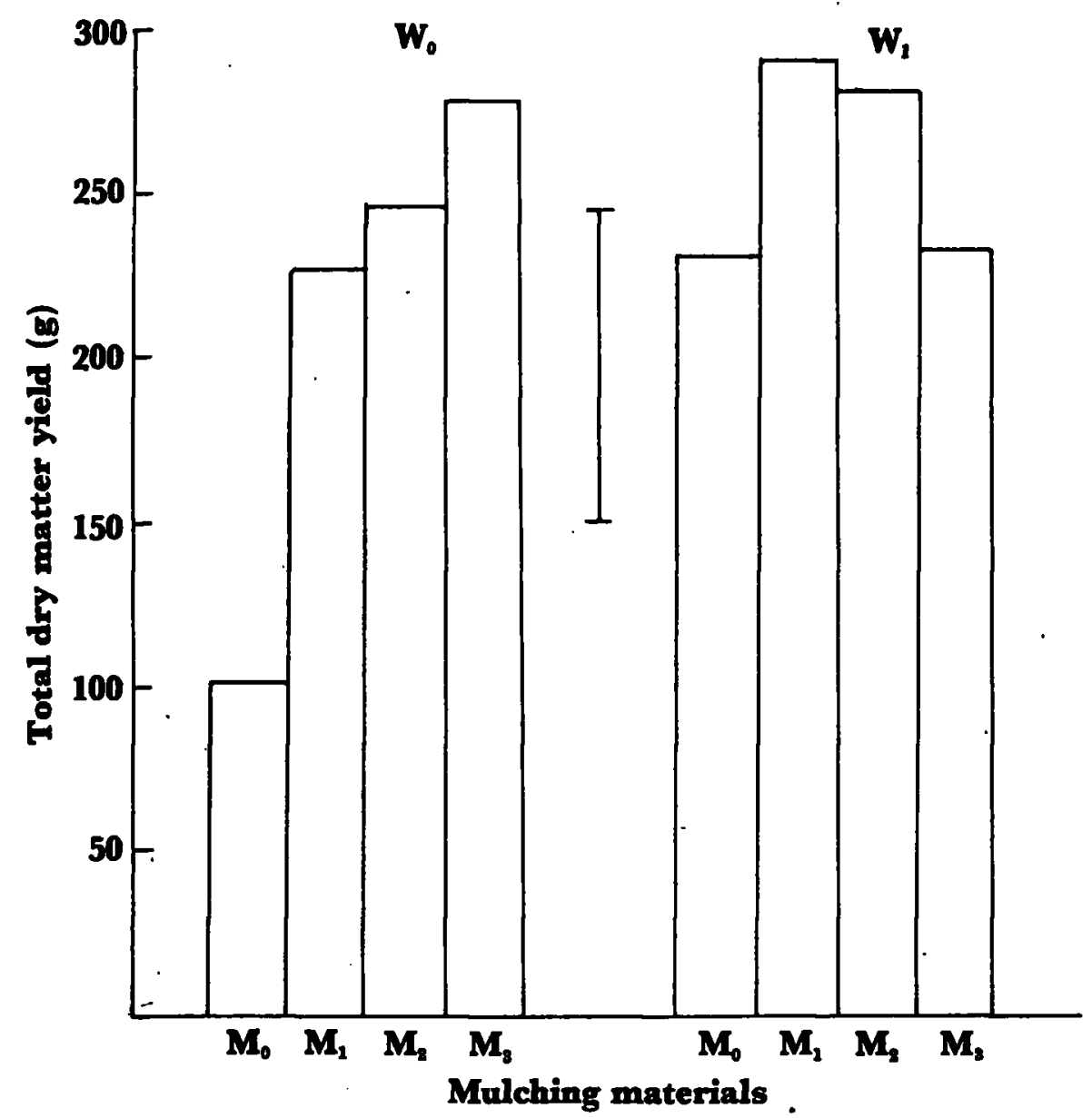

Fig. 3 Effect of weeding $\left(W_{1}\right)$ and no weeding $\left(W_{0}\right)$ on total dry matter yield of coconut seedlings to which four mulch materials were applied. $M_{0}$, no mulch, $M_{1}$, coconut husk, $M_{2}$, bunch refuse; $M_{3}$, grass. Vertical bar represents $L$. S. D. $(P=0.05)$.

Mulching had no effect on soil chemical composition three months after treatment (Table 5) but at the end of the experiment, $K$ content of soil was increased significantly $(P<0.001)$ (Table 6). Bunch refuse and grass increased $K$ more than other treatments. Bunch refuse also slightly increased $P$ content and percent carbon. Weed competition reduced $P$ content of soil $(P<0.05)$, the mean being 24.1 and $27.5 \mathrm{ppm}$ for unweeded and weedfree plots respectively.

The commonest weeds in the polybags were corn grass (Rottboellia exaltata), Ageratum conyzoides, Talinum triangulare, Bracharia sp. and several other sedges. Weed weight differed significantly $(P<0.01)$, the mean being $278.8 \mathrm{~g}$ and $2.7 \mathrm{~g}$ for unweeded and weedfree plots respectively (Table 7). Coconut husk was the most effective material in reducing the weed growth. Polybags mulched with coconut husk were virtually weed-free. 


\section{S. V. REMISON and G, MGBEZE}

Table 4. Effect of weeding and mulching on dry matter yield $(G)$ of coconut

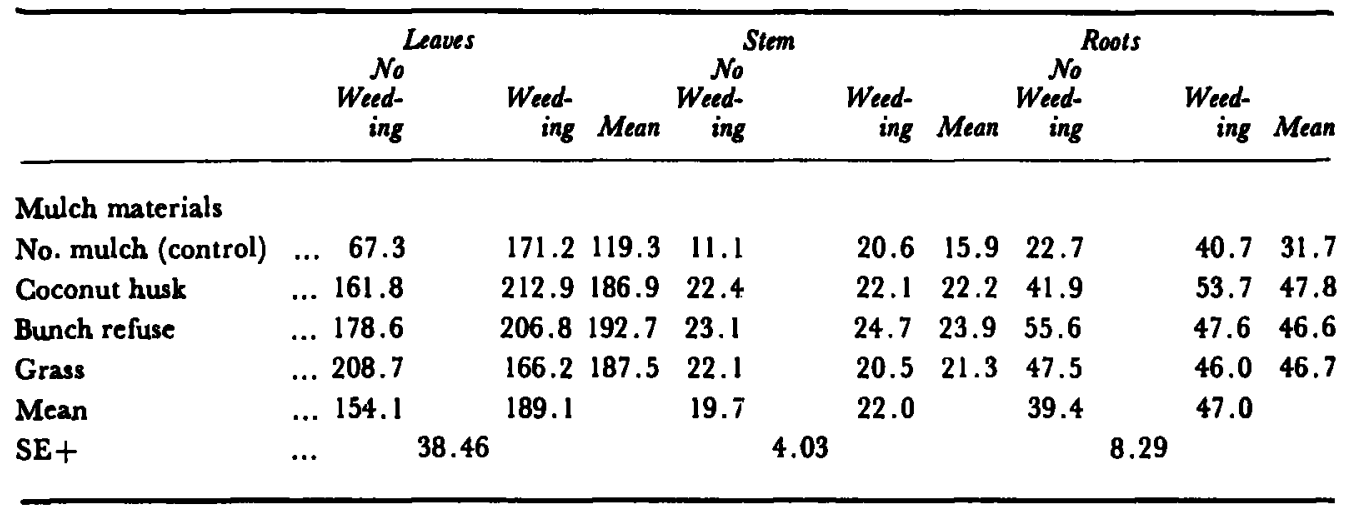

Table 5. Chemical composition of soil three months after mulch treatment

\begin{tabular}{llllllllll}
\hline & & $p H$ & $\begin{array}{c}C \\
(\%)\end{array}$ & $\begin{array}{c}\mathcal{N} \\
(\%)\end{array}$ & $\begin{array}{c}P \\
(p p m)\end{array}$ & $\begin{array}{c}X \\
(m . e q u i v / 100 g)\end{array}$ & $M_{g}$ & $\mathcal{N a}$ \\
\hline Control (no mulch) & $\ldots$ & 6.1 & 1.37 & 0.26 & 6.92 & 0.11 & 2.17 & 1.16 & 2.10 \\
Coconut husk & $\ldots$ & 6.2 & 1.47 & 0.25 & 7.34 & 0.10 & 2.24 & 1.32 & 2.32 \\
Bunch refuse & $\ldots$ & 6.4 & 1.12 & 0.27 & 5.60 & 0.07 & 2.40 & 1.64 & 2.18 \\
Grass & $\ldots$ & 6.2 & 1.25 & 0.26 & 6.04 & 0.08 & 2.24 & 1.76 & 1.99 \\
Mean & $\ldots$ & 6.2 & 1.30 & 0.26 & 6.48 & 0.09 & 2.26 & 1.47 & 2.15 \\
SE+ & $\ldots$ & 0.16 & 0.214 & 0.030 & 1.164 & 0.018 & 0.238 & 0.349 & 0.676 \\
& & & & & & & & & \\
\hline
\end{tabular}

Table 6. Chemical composition of soil at harvest

\begin{tabular}{llccccccccc}
\hline & & $p H$ & $\begin{array}{c}C \\
(\%)\end{array}$ & $\begin{array}{c}N \\
(\%)\end{array}$ & $\begin{array}{c}P \\
(p p m)\end{array}$ & $\begin{array}{c}X \\
(M . e q u i v / 100 g)\end{array}$ & $\begin{array}{c}C a \\
\text { Mulch materials }\end{array}$ \\
\hline Control (no mulch) & $\ldots$ & & & & & & & & \\
Coconut husk & $\ldots$ & 5.2 & 1.20 & 0.09 & 24.02 & 0.15 & 2.17 & 0.93 & 0.07 \\
Bunch refuse & $\ldots$ & 5.3 & 1.28 & 0.11 & 25.96 & 0.18 & 2.24 & 1.04 & 0.09 \\
Grass & $\ldots$ & 5.5 & 1.45 & 0.10 & 27.90 & 0.48 & 1.97 & 0.91 & 0.06 \\
Mean & $\ldots$ & 5.3 & 1.32 & 0.16 & 25.20 & 0.41 & 2.31 & 1.01 & 0.07 \\
SE+ & $\ldots$ & 5.3 & 1.31 & 0.12 & 25.77 & 0.31 & 2.17 & 0.97 & 0.07 \\
& $\ldots$ & 0.121 & 0.091 & 0.0433 & 2.074 & 0.076 & 0.187 & 0.118 & 0.020 \\
\hline
\end{tabular}

Tablc 7. Weed weight $(g)$ in polybag treated with different mulch materials and in weed competition

\begin{tabular}{|c|c|c|c|c|c|}
\hline Mulch Malerials & & No Weeding & & Weeding & Mean \\
\hline $\begin{array}{l}\text { No mulch (control) } \\
\text { Coconut husk } \\
\text { Bunch refuse } \\
\text { Grass } \\
\text { Mean } \\
\text { SE+ } \\
\text { (Weed means) }\end{array}$ & $\begin{array}{l}\cdots \\
\cdots \\
\cdots \\
\cdots \\
\cdots\end{array}$ & $\begin{array}{r}501.68 \\
53.56 \\
308.58 \\
251.31 \\
278.78\end{array}$ & . & $\begin{array}{l}3.74 \\
0.32 \\
2.28 \\
4.59 \\
2.73\end{array}$ & $\begin{array}{r}52.71 \\
26.94 \\
155.43 \\
127.95\end{array}$ \\
\hline
\end{tabular}




\section{Effects of weeds and mulching on Coconut Seedlings}

\section{DISCUSSION}

Weed competition reduced the growth of the coconut seedlings a great deal and the unweeded and unmulched plants were not vigorous enough for transplanting (Fig. 4). Weeds reduced dry matter yield of leaves, stem and roots in unmulched plots by 61.46 and $44 \%$ respectively. These competitive effects were however greatly overcome by mulching. Hence in the mulched plots, irrespective of weeding treatment, dry weight of plant parts did not differ. The major determinants of vigor of nursery seedlings at transplanting stage are height, stem girth and number of green and healthy leaves. These were significantly increased by mulching.

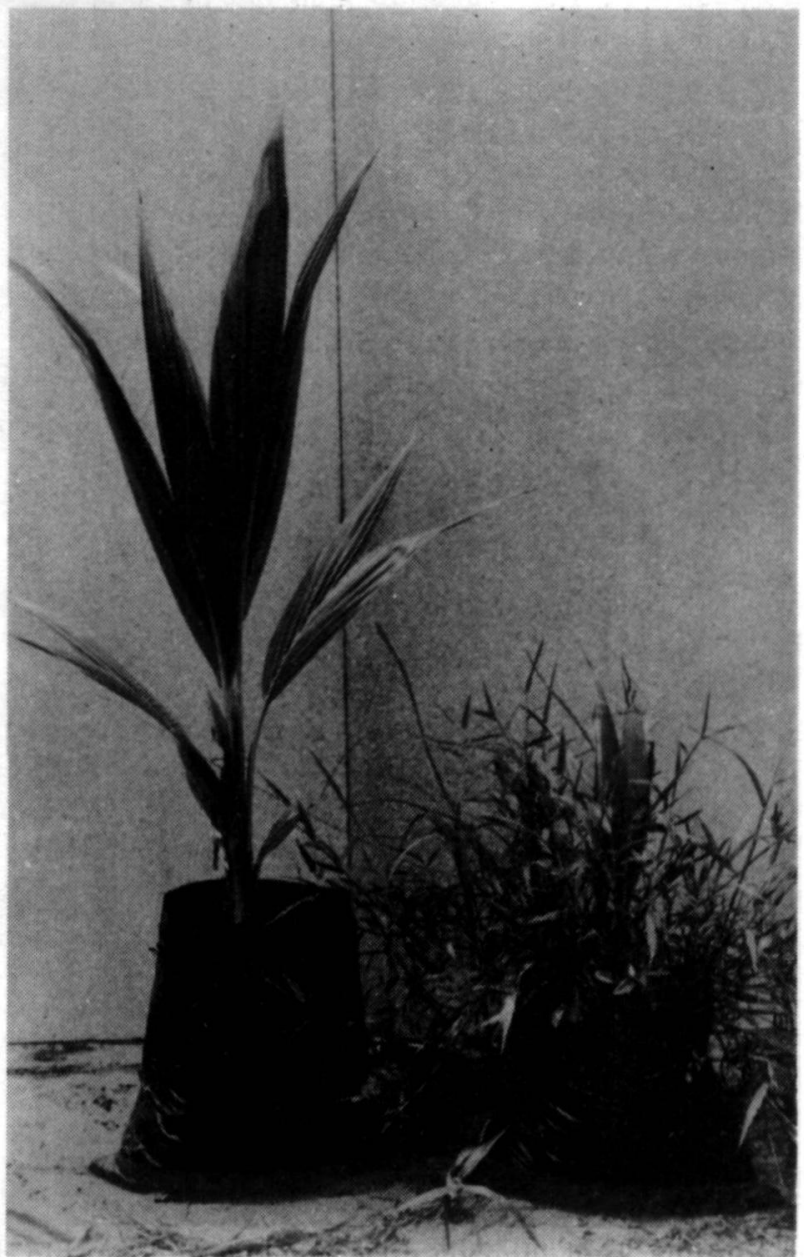

Fig. 4 Six month old seedling mulched with coconut husk and not weeded on the left. Seedling of the same age not mulched and not weeded (control) on the right.

Mulching has been widely used for many fruit trees and tropical plantation crops with superficial root systems. A surface mulch has two types of effects on the soil: a characteristic effect, from its being on the surface of the soil, and a general effect, which it would equally well have if it were ploughed into the soil, due to the plant nutrients set free as it decomposes (Russel, 1961). The primary specific effects of the mulch are confined to the superficial soil layers, which it keeps both cooler and at a more even temperature and damper and more permeable to water than the unmulched soil Soil temperatures 


\section{S. V. REMISON and G. MGBEZE}

were not very much reduced by mulching in this study presumably due to time of the day ( 1 p.m.) when the temperatures were taken. Soil moisture content was not monitored in this study but the unmulched plots were visibly much drier and needed more irrigation during dry spells. Mulching presumably slows down the rate of evaporation from a wet soil very considerably.

The chemical analysis of soil at harvest (Table 7) showed that a lot of $\mathrm{K}$ was released to the soil by the mulch materials especially oil palm bunch refuse and grass. G.O. Iremiren (personal comm) also found an increase in soil $K$ and $P$ with the use of bunch refuse in polybag oil palm nurseries. The most satisfactory mulch material has been reported to be finely divided bunch refuse (Hartley. 1977; Anon, 1982). Large quantities of $\mathbf{K}$ are diverted to the oil palm bunches but relatively low quantities to the fruits. Though $\mathbf{P}$ uptake is much smaller than $\mathbf{K}$ uptake, the proportion of $\mathbf{P}$ diverted to the bunches is also large. Lower proportion of $\mathrm{N}, \mathrm{Mg}$ and $\mathrm{Ca}$ are removed in the bunches. Hence residual contents of these elements were low at harvest in this study. Compared with the original level at the beginning of the experiment, residual $\mathrm{N}$ in the soil at harvest was less than half. Coconut husk contains large quantities of $K$ and Ouvrier and Ochs (1978 noted that the husk removed more nutrients than any other part of the fruit and percent $\mathrm{K}$ removed was higher than any other element. But surprisingly, not much of $\mathrm{K}$ or any other element was released to the soil with coconut husk mulch in this study.

The findings here have many practical implications. The results show clearly that mulches are valuable not only in conserving soil water and increasing permeability but also in increasing the amount of exchangeable $\mathrm{K}$. Additionally mulching should reduce labour on weeding. Child (1964) has cautioned that though mulching is valuable in coconut culture, with most available materials, the possibility of encouraging the activity of termites must be borne in mind. The activities of termites are location specific and in environments where they are not a threat, muching should constitute a useful cultural practice. The mulches used in polybag nurseries in Nigeria depend on availability of material. For instance, at the Main Station of NIFOR Near Benin, the Sub-station at Abak and the outstation at Onishere, it is relatively easy to use oil palm bunch refuse. At the coconut sub-station near Badagry where bunch refuse is not easy to come by, shredded coconut husk is used. In the alternative grass and even dry tree leaves could be used.

\section{REFERENCES}

Anon (1982). Nineteenth Annual Report of the Nigerian Institute for Oil Palm Research pp. 29.

Bevan; J. W. L. and Gray, B. S. (1969). The organisation and control of field practice for large scale oil palm planting in Malaysia. Kuala Lumpur: Incorporated Society of Planters.

Chang, A. K. (1978). An investigation into the optimum period of retention of MAWA coconut seedlings in polybag and field nurseries. Proc. Int. Conf. on cocoa and coconuts, Kuala Lumpur p. 568-578.

Child, R. (1964). Coconuts 216 p, Longmans Group Ltd., London.

Hartley, C. W. S. (1977). The oil palm, 2nd ed, Longmans Group Ltd., London.

Komolafe, D. A., 1978. Weeds and their control in perennial plantation crops in Nigeria.

In : Weeds and their control in the humid and subhumid tropics. Proceeding Series

No. 3, IITA, Ibadan, 344-349. 


\section{Effects of weeds and mulching on Coconut Seedlings}

Okigbo, B. N. (1978). Weed problems and food production in developing countries. In : Weeds and their control in the humid and subhumid tropics. Proceeding Series No. 3 IITA, Ibadan, 1-11.

Oladokun, M. A. O. (1978). An assessment of cultural weed control methods in Coffea canephora. In : Weeds and their control in the humid and subhumid tropics. Proceeding Series No. 3 IITA, Ibadan, 362-365.

Ouvrier, M. and Ochs, R. (1978). Nutrient removal by hybrid coconut Port-Bonet 121 (MAWA). Proc. Int. Conf. on cocoa and coconuts, Kuala Lumpur, 595-605.

Wuidart, W. (1981). Production of coconut planting material. The polybag nursery. Oleagineux 36, 372-374.

Remison, S. U. (1979). Effect of weeding and nitrogen treatments on maize yields in Nigeria. Weed Research 19, 71-74.

Russell, E. W. (1961). Soil conditions and plant growth, 9th ed. Longmans Group Ltd., London. 